\title{
Hyang Iwak
}

\section{Edi Triharyantoro}

Keywords: deities, fish, Hindu, supranatural, inscription

\section{How to Cite:}

Triharyantoro, E. Hyang Iwak. Berkala Arkeologi, 14(2), 56-59. https://doi.org/10.30883/jba.v14i2.644

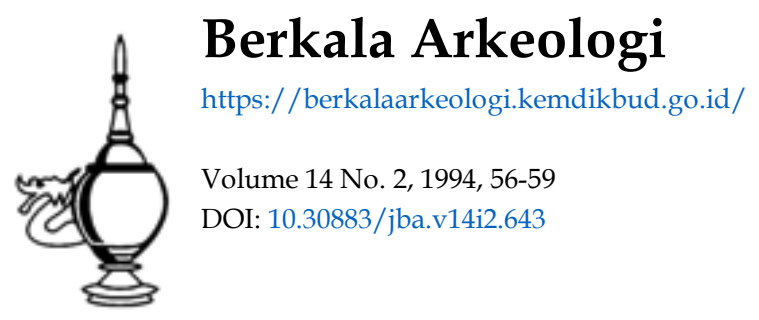

\section{@(@) $\Theta(\odot$}

This work is licensed under a Creative Commons Attribution-NonCommercial-ShareAlike 4.0 International License. 


\title{
HYANG IWAK
}

\author{
Edi Triharyantoro \\ (SPSP Provinsi Jawa Timur)
}

\section{Pendahuluan}

Bagı masyarakat Jawa, alam empiris dianggap berhubungan erat dengan alam metemperis (alam gaib) Menurut pandangan mereka bahwa realitas tidak dibagi dalam berbagai bidang yang terpisah-pisahkan dan tanpa hubungan satu sama laın. melainkan bahwa realitas dilihat sebagai suatu kesatuan yang menyeluruh. Bahkan secara tegas Franz Magnis Suseno mengatakan, bahwa hakekatnya orang Jawa tidak membedakan antara sıkap-sıkap religius, dan interaksi-ınteraksi sosıal sekıgus merupakan sikap terhadap alam, sebagaımana juga sıkap terhadap alam sekaligus mempunyar relevansi sosial (Mulder, 1873:36; Franz Magnis Suseno, 1991:82).

Sikap terhadap alam tersebut tentu saja digerakkan oleh intelegensi serta kehendak-kehendak bebas manusia yang secara kodrati menjadi dasar bagı terciptanya kebudayaan. Salah satu yang menarik dari sıkap budaya Jawa terhadap alam dengan aspek relevansi sosialnya itu adalah pandangan mereka terhadap binatang ikan. Dalam 'konteks budaya', nampak bahwa sikap mereka terhadap binatang ikan itu merupakan manifestasi budaya universal dan dapat hidup berabad-abad, bahkan sampai keluar Jawa.

Tulısan singkat ini berangkat dari artefak ıkan (arca) yang menjadi koleksi Suaka Peninggalan Sejarah dan Purbakala Jawa Timur. Arca tersebut darı batu dengan ukuran panjang $54 \mathrm{~cm}$, lebar $15 \mathrm{~cm}$. Nomor inventaris arca 241.0103. Arca berasal darı Desa Wonosalam, Kecamatan Wonosalam, Kabupaten Jombang

Keadaan arca masih bagus. Darı bentuknya diketahuı jenıs ikannya adalah (Jawa=bader). Badan pıpıh dengan garis mata tajam. Sisık-sisiknya tıdak merata hanya digambarkan pada tubuh bagian depan Ekornya melıpat ke depan. Salah satu yang menarik perhatian ralah adanya angka tahun yang ditulis dengan huruf Jawa Baru dan dipahatkan pada bagian bawah tubuhnya dekat ekor. Tulisan itu berbunyi: satu Syura 1655

\section{Jagat Ikan}

\section{A. Masa Hindu-Buddha}

Pada masa-masa yang sangat tua, pemujaan terhadap bınatang merupakan gejala budaya yang bersıfat universal misalnya terdapat di Mesopotamıa, Indıa, Cina, Mesir, dan Jepang. Kebudayaan Mesopotamıa misalnya banyak menga. dopsi binatang sobagai simbol. Beberapa dewa mempunyal atribut binatang yang kadang-kadang digambarkan di sampıng dewa atau berdirı di atas dan di belakangnya. Bahkan secara khusus unsur binatang digambarkan secara mandiri seperti terdapat di Kassite Kudurus

Dalam kertas kejanya yang dipublikasıkan pada tahun 1939, seorang arkeolog terpandang Douglas van Buren, mengumpulkan catatan mengenai seluruh spesies binatang yang digambarkan pada monumen-monumen di Mesopotamia. Di antara binatang-binatang tersebut terdapat jenis singa, panther, kucıng liar, srigala, anJing, beruang, lumba-lumba dan ikan iJ.M Aynard, 1972:43).

Di India tradisı yang menjelaskan hubungan binatang dan manusia terdapat dalam kepercayaan mengenai "perpindahan jıwa". Kepercayaan ini terdapat dalam Veda kuna yang kemudian diterima pada Jaman Upanısad sekitar abad VI SM. Essensi dari doktrin tersebut ıalah bahwa kelangsungan hidup dari kematian dapat berpindah ke dalam tubuh lain sesuai dengan tingkah lakunya di dunia. Rantai kelahiran kembalı tersebut berputar ibarat berputamya roda cakra, sampai jiwa tersebut bebas lepas dari beban perbuatan buruknya, kemudian bergabung dengan "universal self". Reinkarnasi itu dapat berbentuk binatang atau manusia sesuai dengan jasa-jasanya di dunia.

Ikan sebagai binatang mitos sangat dikenal dengan baik dalam agama Budha maupun Hindu. Sebagai contoh simbul dua ekor Ikan (Matsya-Yugma) mempunyai makna sendiri-sendiri dalam agama Budha dan Hindu. Dalam agama Budha, Matsya-Yugma berarti lambang kebaha. giaan dan persatuan atau salah satu bentuk dan astamanggala. Sedang dalam agama Hindu Matsya-Yugma adalah lambang dua sungai sucı yaitu Gangga dan Yamuna. Ikan dalam agama Hindu juga dianggap kendaraan Dewa Varuna atau Dewi Gangga. Solain itu juga dipakaı sebagai atribut oleh Gauri, Sivaduti. Virahi serta me. rupakan salah satu avatara yang sangat terkenal dari Dewo Wisnu sebagai Matsya-Avatara

Di Indonesia, khususnya di Jawa figur ıkan menduduki tempat yang religius dan masih kuat dipengaruhi oleh keyakinan-keyakınan darı India Manifestasınya masih dapat dijumpaı dalam $k_{1}$ tab-kıtab kesusastraan, relief-relıef, arca-arca serv prasasti. 
Dalam Adiparwa disebutkan bahwa ada seorang raja bemama Basupariçara yang memuja Dewa Indra ketıka sedang berburu, maharaja Basuparıçara melihat bunga-bunga yang mekar, sehıngga terıngatlah ia akan kemolekan permaisurınya Dewı Girika. Oleh karena itu keluarlah air kamanya yang kemudian ditampung dengan sehelai daun. Kemudian dipanggillah seekor burung elang laın sehingga daun dari yang kena kutuk. Ikan tersebut lalu buntıng dan lahirlah dua bayi lakı-laki dan perempuan, yang laki-laki bernama Matsyapt yang kemudian menjadi raja Wirata, sedangkan yang perempuan bernama Durghandini karena baunya sepertı ikan. Durghandini lalu kawın dengan Bagawan Paraçara dan dari keduanya ınilah akhımya secara turun menurun lahir keluarga Pandawa (Adiparwa, 1958:85-87)

Dalam kitab yang lebih muda yaitu Tantri Kamandaka, terdapat pula tentang dongeng ikan tiga bersaudara. Inti ajaran moral dari dongeng itu Ialah barang siapa berdaya upaya lebih dahulu, dan bijaksana dalam hal keduniawian, pasti akan mendapatkan kesenangan. Dan yang meremehkan kasıh sayang saudaranya, itu namanya tanpa pikıran, bermain-maın untuk menemukan ajalnya (L. Mardiwarsito, 1983:101-103).

Darı kedua kitab susastra di atas dapat dipahamı bahwa mitos ikan mempunyai makna yang berbeda. Di satu sisı dalam adiparwa ikan merupakan bagran yang sangat penting dari isi cerita secara keseluruhan. Sebab di situ disebutkan bahwa ıkan-lah yang pada dasarnya menjadi cıkal bakal darı keluarga Pandawa. Meskıpun tidak dijelaskan secara gamblang siapa sebenarnya sı Ikan itu sendın karena hanya dıkatakan sebagaı perwujudan darı bidari yang kena kutukan. Sedang dalam Tantri Kamandaka, figur ikan tidak berkaitan dengan tokoh-tokoh sentral cerita yang meresap di sanubari masyarakat. Dengan demikıan ıkan semata-mata dipakaı sebagaı media untuk menyampaikan pesan-pesan moral.

Ikan sebagai mitos yang bermakna kepercayaan sekaligus mampu menyampaikan pesanpesan moral dapat pula dijumpai dalam bentukbentuk relief-relief Sri Tanjung. Seperti diketahui bahwa pesan moral itu nampak ketika Sri Tanjung mempertahankan kesetraannya kepada Sidapaksa dengan mengorbankan nyawanya (Poerbatjaraka dan Tarjan Hadidjaja, 1952:90-92) Dalam relief, perjalanan roh Sri Tanjung digambarkan naik ikan lumba-lumba Relief ini dapat dijumpai pada Candi Bajangratu, Panataran, Jabung: dan sebagainya. Satu hal yang menarik dipertanyakan ialah jenis ikan lumba-lumba yang mana. Pertanyaan itu tidak mudah dijawab, tapi hanya dapat diperkirakan bahwa lumba-lumba justru sudah akrab dengan manusia selak masamasa tua
Adapun ikan yang digambarkan dalam wuJud arca terdapat di Gedung Arca Mojokerto Informasi mula-mula tentang arca inı terdapat di dalam laporan Belanda ROC 1907. Disebutkan dalam laporan itu bahwa di Dukuh Bata-Paloeng distrik Mojokerto, terdapat arca ikan yang oleh penduduk setempat disebut Bata-Paloeng atau Ikan-Paloeng. Arca itu berukuran besar dengan ukuran tinggi $1 \mathrm{~m}$. sedang kelilingnya $2.4 \mathrm{~m}$

Proporsı ikan Bata-Paloeng yang besar tersebut dapat dikaitkan dengan mitologi avatara Wisnu yang pertama yaknı Matsya-Avatara yang juga dilambangkan sebagai ikan besar. Disebutkan dalam mitologi bahwa ketika dunia diserang banjir dan tenggelam, ketika itu pula setan merebut Veda dari Sang Pencipta dan kemudian menceburkannya ke lautan Matsya yang kemudian menolong Manu untuk mendapatkannya lagi. Cerita lain menerangkan bahwa ketıka dunıa tenggelam, Manu manusia pertama ditolong oleh seekor ikan besar (Jhasa) yang sebenarnya merupakan pengejawantahan Wisnu di dunia Ketika perahu sudah akan tenggelam, Manu kemudian menggunakan Naga Vasuki untuk tainna yang diikatkan pada tanduk Jhasa. Oleh Jhasa perahu tersebut kemudian ditarik menuju ke sebuah gunung sehingga selamatlah Manu dan selamattah manusia (Margaret Stuttley, 1985:91)

Dalam konteks historis terdapat pula prasas ti yang berlencanakan sepasang ikan yang dikeluarkan oleh Jayanegara pada tahun $1323 \mathrm{M}$ Penggalan prasasti itu berbuny! " sesual dengan perintah Sri Bag'nda Maharaja kepada Desa Tuhanyaru dan Kusambian, maka perıntah ra Ja yang mulia itu supaya dilaksanakan dan diber lencana sepasang ikan. " (Muhammad Yamın, 1962:51)

Darı uraıan di atas dapat diajukan hıpotesa bahwa Jayanegara mempunyai ikatan relıgius dengan unsur Ikan Adanya arca yang sangat besar ditemukan di wilayah Majapahit itupun pada dasarnya merupakan indıkası bahwa arca tersebut merupakan pengejawantahan jayanegara titisan Wisnu sebagai Matsya-avatara Hipotesa in pat dianalogikan dengan iklim poiitik pada waktu pemerintahan Jayanegara. Telah diketahur bahwa pada waktu pemenntahannya banyak terjadı konflik politik berupa pemberontakan Sebagal upaya untuk menyelamatkan kerajaan yang me rupakan pusat magis dan pusat pemenntahan wajar kiranya bila Jayanegara kemudian melegıtimasikan dirınya sebagaı Matsya-Avatara (Edi Triharyantoro, 1992:253;

inensitas religius tentang Ikan yang paing menonjol terdapat dalam prasasti Jayanegara । berangka tahun $1316^{\circ} \mathrm{M}$ isi prasasti itu pada dasamya adalah rasa syukur Jayanegara atas terselesaikannya pemberontakan đl Walambangan Penggalan prasastı sebagal berikut ya 
tikěnuwuhaka punwarěna asma-asma rımanah Çri Mahärāja matangya anurun anugraha Çrimahārāja / rıkanang karāmān I balambangan, an sumina taninya / blambangan, tanı watěk er tani madrabyahaji maułahakna pamujjā hyang iwak, sakınabhaktyanya $r$ lagı pahalanyān suștu bhaktı rı Çrimahärāja .. ". Yang artinya "... hail itu menımbulkan rasa terima kasih yang tak ada bandingnya dalam hati sanubari Sri Baginda Maharaja. itulah yang menyebabkan Sri Baginda Maharaja menurunkan anugerah kepada masyarakat Belambangan, yaitu mengangkat daerah Belambangan itu menjadı sebıdang tanah perdikan sıma. Daerah pesukuan Air-Tani kini diperkenankan memungut hasil hak raja; benda-benda pembaktian menurut pahalanya, sebagai kesetiaan yang sungguh-sungguh kepada Sri Baginda Maharaja "(Muhammad Yamin, 1962:37-38).

Darı isı prasasti tersebut dapat difahami bahwa pemujaan kepada Hyang I wak merupakan aktivitas sosial sakral yang disejajarkan dengan pemujaan terhadap benda-benda suci lainnya. Maklumat Jayanegara yang mengınginkan dilakukannya pemujaan kepada Hyang Iwak itu pada hakekatnya merupakan refleksi sosial atas ideologi legitimasi kekuasaannya. Tataran ideologi itu menjadı lebih konduksif ketika unsur-unsur kesuburan (pertanian) merupakan ciri kehidupan sosial masyarakat pendukungnya

\section{B. Kontinuitas}

Sepert sudah disinggung sebelum ini bahwa Suaka Peninggalan Sejarah dan Purbakala Jawa Timur juga mempunbyai arca ıkan laın berukuran kecıl darı jenis (Jawa=bader). Salah satu yang menarik dari arca tersebut ialah adanya angka tahun yang ditulis dengan huruf Jawa Baru dan dipahatkan pada bagian tubuhnya. Angka tahun itu berbunyı 1 syura 1965

Rupa-rupanya data ikan itu merupakan data tertua setelah periode klasik. Sebab bila dibandingkan dengan upacara-upacara sucı yang berkaitan dengan Hyang I wak yang dilaksanakan pada masa-masa sekarang akan nampak adanya kesejajaran

Sebagai misal pada upacara bersih desa yang dilakukan oleh masyarakat Simbatan Wetan, Kecamatan Takeran, Kabupaten Magetan, Jawa Timur. Oleh karena upacara itu bersifat sakral, maka dipilih hari dan bulan yang dianggap suci Menurut adat yang berlaku secara turun-temurun, upacara bersin desa di Simbatan Wetan dilakukan pada setiap bulan Syuro pada hari Jum at pahıng. Dahulu ketika petirtan Simbatan inı masih berfungsi sebagai irigasi, para pemujanya adalah masyarakat yang sawahnya mendapat pengairan darı petirtan tersebut

Upacara itu diawali dengan selamatan membagıkan makanan kepada yang hadır. Sete- lah mengadakan selamatan para sesepuh desa kemudian mengadakan "melekan" semalam suntuk. Keesokan harınya, harı Jum'at pahing mereka membersihkan kolam Setelah air lumpur yang terdapat di kolam berkurang, orang beramai-ramai menangkap ikan gabus yang hidup di kolam tersebut. Ikan-ikan gabus itu dihormat, oleh penduduk dan tak seorang pun beran: mengganggu apalagi membunuhnya. Tujuan ints pengurasan kolam adalah dianggap mampu mengabulkan segala keıngınan

Setelah pembersihan kolam kemudian diadakan tayuban dengan tari-tarıan. Menarik perhatian adalah pada saat didendangkan lagu dan gending, ikan gabus yang telah ditangkap dibawa menari-narı. Setelah dianggap cukup, ikan-ikan gabus itu kemudian dilepas kembali ke dalam kolam dan ditaburi beras kuning Penaburan beras kunıng itu dimaksudkan untuk memberı makan ikan gabus dengan harapan mereka akan mendapat berkah (Hartini, 1983:66-68).

Hal yang dapat ditarik sebagai kesımpulan dari data arca ikan berangka tahun 1 syuro 1655 dengan upacara bersih desa di petirtan Simbatan Wetan adalah waktu pelaksanaanya yang seragam yaitu bulan Syuro. Dengan demikıan dapat disimpulkan bahwa bulan syuro dianggap sebagai bulan yang keramat yang ada kaitannya dengan masalah kesuburan

Data etnologi lain yang dapat dibandingkan ialah kepercayaan masyarakat Flores mengena: nenek moyang mereka. Sebuah mitos mengisahkan, seorang laki-laki, Roru, dan seorang perempuan, Modo, turun darı langit ke Nusa Endeh Seorang anak lakı-lakı Roru menikah dengan anak gadis Ambu Nggobe (Ambu Nggobe adalah tuan tanah dari seberang). Anak gadis mereka menikah dengan seorang laki-laki yang datang dari Majaphit naik ikan paus. Jika seekor ikan paus menampakkan din di teluk, secara teratur masih disediakan korban (F.A.E van Wouden, 1985:78)

\section{Penutup}

Ikan dalam kondisı religiusıtas dı\}umpa pertama kalı dalam kitab Adıparwa jaman Dharmawangsa Teguh Figur ikan dalam susastra itu mempunyai peranan yang besar karena dıdentıfikasıkan sebagaı bıdadarı yang menurunkan keluarga besar pendawa.

Pada masa Majapahit Ikan justru mempunyai kedudukan yang tinggı sederajat dengan dewa-dewa dalam agama Hindu. Bahkan pemujaan terhadap Hyang Iwak secara eksplisit terdapat dalam prasasti Jayanegara I $1316 \mathrm{M}$.

Pada masa-masa sekarang mitos Ikan dikaitkan dengan unsur-unsur kesuburan atau digunakan sebagai media untuk menyampaikan pesan-pesan moral 


\section{KEPUSTAKAAN}

Aynard,J.M.,1972, Anımal in Mesopotamia, dalam Animal in Archaeology. USA=Praeger Publisher.

Edı Triharyantoro, et.al.,1992, Seni Majapahit dalam 700 Tahun Majaphit.Surabaya:Diporda Provinsi Jawa Timur

Franz Magnis Suseno,1991, Etika Jawa Sebuah Analisis Falsati tentang Kebijaksanaan Hidup Jawa, Jakarta:Gramedia.

Mardiwarsito,L., 1983. Tantri Kamandaka, Flores Kanisius

Muhammad Yamırı, 1962,Tata Negara Majapahit, Jakarta:Yayasan Prapantja

Nurder, Neils, 1973, Kepribadian Jawa dan Pembangunan Nasional, Yogyakarta:Gadjah Mada University Press

Siman Widyatmana, 1958, Adiparwa, Yogyakarta Up "Spring".

Stuttley, Margaret.1985, The Dictionary of Hindu Ichonography, London:Rouledge \& Kegan Paul.

Wonden van FA.E., 1985, Klen, Mitos dan Kekuasaan Struktur Sosial Indonesia Bagian Timur, Jakarta:Grafiti Press 